\title{
Individual trauma and national response to external threat: The case of Israel
}

\author{
SAM S. RAKOVER and A. YANIV \\ Haifa University, Haifa, Israel
}

\begin{abstract}
This study explores the psychological underpinning of escalation in international conflicts. An analogy, the "vicious circle of war" hypothesis, was drawn between the behavior of rats in Mowrer's experiment concerning the phenomenon of the "Vicious circle of fear" behavior and the reactions of human individuals to the recurrent experience of war. A number of predictions are derived from the "Vicious circle of war" hypothesis and subsequently confirmed by the results obtained from a survey.
\end{abstract}

Theorists concerned with the psychological dimensions of international conflicts suggest that nations in conflict tend to become entrapped in what might be termed "escalating mutual distrust" (cf. Deutsch \& Senghaas, 1971; Gladstone \& Taylor, 1958; Holsti, 1962; Pruitt, 1965; Scott, 1965; Zinnes, 1962). A psychological model will be offered that seems to explore the dynamics leading to the "escalation of distrust" in the case of the individual. We propose an analogy based on Mowrer's (1947) theory and experimental evidence known as the "vicious circle of fear" (for a review see Brown, 1969; Renner \& Tinsley, 1976). The paradigmatic experiment that Mowrer and his followers carried out proceeded as follows: A group of rats was trained to escape an electric shock produced in a startbox and to run through a straight alley to a goalbox. Once trained in this manner, the group was divided in half. The running response of the control group was extinguished simply by eliminating the shock. In the experimental group, however, the shock was moved from the startbox to the alley. Paradoxically, it was found that the escape response of the experimental group was not only extinguished much more slowly than that of the control group, but in some cases was even invigorated by the punishment in the alley.

According to Mowrer's (1947) theory, the startbox aroused fear in the rats through the pairing of the startbox with the shock. In the control group, the escape response was extinguished because of a progressively diminishing fear resulting from the elimination of the shock. In contrast, the fear in the experimental group aroused by the startbox was not extinguished but, rather, was reinforced by a new source of fear in the alley. Through a process of stimulus generalization, the

Requests for reprints should be addressed to Sam Rakover, Department of Psychology, Wayne State University, Detroit, Michigan 48202. Special thanks go to R. Hansen and D. Ronis, who read the manuscript and made helpful suggestions. The writing of this article was funded by Oakland University, Rochester, Michigan. fear aroused in the alley was added to the fear aroused earlier in the startbox, thus causing the rats to run from the startbox to the goalbox through the electrified alley in a vicious circle that amounted to self-punishment.

The above suggests an intriguing analogy. A war to a nation, or at least to those among its members who suffer from the war, may be likened to the electric shock that Mowrer (1947) administered to the rats. Hence, the experience of war should produce an acute sense of fear and insecurity. Similar to Mowrer's theory, fear, as a hypothetical construct, is defined here by the antecedent conditions, namely, the war. That is, people who were injured in a war tend to be in a stronger state of fear than people who were not injured in a war. The upshot is a policy that seeks security (i.e., fear reduction) through reliance on military power. This response to fear of war is analogous to the running response of Mowrer's rats. Further, the fear aroused by the second war in the sequence (the shock in the alley) reinforces the residual fear aroused by the initial war. Consequently, faith in military force is maintained or invigorated.

This analogy, to which we shall refer as the "vicious circle of war" hypothesis, has to be qualified. First, international interactions are a ceaseless sequence in which it is impossible to point to a zero point of initiation, as was clearly the case in Mowrer's (1947) laboratory experiments. Second, an increased reliance on security through force does not inevitably lead to further wars, since nations, while preparing for further wars, may well avoid them. That is, we predict an increase in the attitude favoring security through force, but not necessarily a self-fulfilling prophecy that this attitude will be the cause of a new war. Finally, it should be noted that Mowrer's experiment and theory are nothing more than a guide and source of suggestions for the development of the vicious circle of war hypothesis. This research tests the latter and not the former theory.

We tested this hypothesis in the case of Israel. Personal impressions indicated that the 1973 Yom 
Kippur War, more than any other war that Israel has experienced, invoked at a stroke a whole universe of associations, images, and memories of the holocaust that had long been dormant, and which amounted to a profound fear of annihilation. Accordingly, we concluded that it would be most appropriate to test our vicious circle of war hypothesis with reference to World War II and the 1973 Arab-Israeli War.

With these considerations in mind, we made three predictions. First, people who suffered physical injury during World War II and/or the 1973 war would tend to emphasize the need for security based on force more than those who suffered no such injury. World War II created a fear of annihilation. Israel's successful wars with her neighbors in 1948, 1956, and 1967 reduced this fear. However, the 1973 Yom Kippur War severely undermined this sense of security and, according to the vicious circle of war hypothesis, reinvigorated the old fears. In turn, people with such an experience should tend to put an even greater store in what we describe as "security through force." Second, nonphysical injury such as economic loss is presumably far less fear arousing than physical injury. Hence, the difference in views on the role of force in attaining security between people who suffered such losses in both instances and those who did not should be much smaller than the difference between people who were physically hurt and those who were not. Third, the outcome of the 1967 6-Day War seemed at the time to have vindicated the validity of security through force and further weakened fear of annihilation. Therefore, it was expected that rating the question of security through force, retrospectively, as the subject would have done had he been requested to do so after the 1967 6-Day War would be the same for those people who did or did not suffer in World War II and the Yom Kippur War either physically or economically. Also, in comparison with subjects who were not hurt, subjects who were hurt would assign higher rankings to security as a national goal after the 1973 war than after the 1967 war. If these last two predictions are confirmed in spite of the rearousal of fear of annihilation after the 1973 Yom Kippur War, then they will be doubly confirmed.

\section{METHOD}

\section{Questionnaire}

On the basis of a pilot study, an anonymous questionnaire was prepared. It contained the following six questions: First, there was a standard socioeconomic question. Second, a question asked for which party the subject voted in the seventh (1969) Knesset (parliamentary) elections and the eighth (1973) elections. Third, the subject was asked to rank order his reasons for the 1973 vote by reference to the following national goals: peace, security through force, settlements in the occupied territories, domestic, social, economic and religious problems, foreign affairs, and immigration. The fourth question in the questionnaire was whether the subject had suffered a physical or an economic injury in the Yom Kippur War either personally or through his relations or close friends. The fifth question on the questionnaire requested the subject to rank order the six national goals listed above as he would have done had he been requested to do so in the wake of the 1967 6-Day War and separately after the 1973 Yom Kippur War. The final question requested that the subject state whether he, his relations, or close friends, suffered a physical or an economic injury in World War II.

\section{Procedure and Subjects}

The questionnaire was circulated during a 2-month period immediately following the election to the eighth Knesset, which took place in the wake of the 1973 Yom Kippur War. Three hundred and fifty-nine Jewish students at Haifa University were requested to answer the questionnaire. A brief explanation of the purpose of the study was offered to them 6 months later.

\section{RESULTS}

The sample was divided into four independent groups by cross-cutting the two variables: being hurt or not being hurt in World War II or in the 1973 war. The four groups were as follows: not hurt in World War II or in the 1973 war $(n=22-24)$, not hurt/hurt $(\mathrm{n}=54-58)$, hurt/not hurt $(\mathrm{n}=35-43)$, and hurt/hurt $(n=225-233)$. The differences in cell $n s$ were due to failure of some subjects to answer all the questions. These constituted the independent variables, and ranking of the national goals constituted the dependent variable. Since emphasis on security based on force is the Israeli national response to the fear of annihilation, each subject was awarded a point only if he ranked security through force in first place. Statistical analyses were made by multidimensional chi-square tests (see Winer, 1971). Nonsignificant relationships were found between the independent variables and age, sex, and community. The only obvious exception was that western community students (e.g., parents coming from Europe) were injured by World War II more than students coming from eastern communities (e.g., Arabic countries). However, this demographic fact cannot account for the present research results.

The following results support the vicious circle of war hypothesis in that fear aroused by World War II and/or the Yom Kippur War increased the tendency to rank security in first place. Security as the reason for voting for the 1973 eighth Knesset was listed in first place by $37 \%(102 / 279)$ of the students who suffered physical injury in the Yom Kippur War, but by only $20 \%(12 / 59)$ of those who were not hurt in this war [i.e., $17 \%$ more by the former group than by the latter; $\left.\chi^{2}(1)=5.87, p<.02\right]$. The percentage of students who were hurt in the Yom Kippur War was $82.50 \%$ (279/338).

Security as the national goal after the Yom Kippur War was ranked in first place by $41 \%(117 / 228)$ of the students who were physically hurt in the Yom Kippur War, but by only $23 \%(15 / 66)$ of those who were not hurt in this war [i.e., $18 \%$ more by the former group than by the latter; $\left.\chi^{2}(1)=7.82, p<.01\right]$. A significant triple interaction among World War II, the Yom Kippur War, and security was found $\left[\chi^{2}(1)=7.40, p<.01\right]$. 
Further, specific chi-square tests showed that this interaction could be attributed to the group of subjects who were physically hurt in World War II and in the Yom Kippur War. Forty-one percent $(95 / 233)$ of the subjects who ranked security in first place were hurt in World War II and the Yom Kippur War, whereas 24\% (10/42) were hurt only in World War II $\left[\chi^{2}(1)=4.28, p<.05\right]$. The percentage of students who were hurt in the Yom Kippur War was $81.36 \%(288 / 354)$, and in World War II, $77.70 \%(275 / 354)$.

According to the vicious circle of war hypothesis, because of the swift victory of the 6-Day War, no fear of annihilation had been aroused, and, therefore, retrospective ranking of security should not be different among those who were or were not physically hurt in World War II and the Yom Kippur War. This prediction was borne out. No significant relationships were found between people who were or were not hurt in World War II or the Yom Kippur War in retrospective ranking of security as a national goal after the 6-Day War. Another way to test this last prediction concerning the 6-Day War is by comparing the ranking of security as the national goal after the 6-Day War with the ranking of that goal after the Yom Kippur War. The sample was divided into three groups: those who ranked security as the national goal after the Yom Kippur War as higher than, equal to, and lower than after the 6-Day War. This comparison takes into consideration relative rankings, and it includes, therefore, rankings of security that were not in first place. Security as the national goal was ranked higher after the Yom Kippur War than after the 6-Day War by $43 \%(119 / 274)$ of the students who were physically hurt in World War II, but by only $31 \%(25 / 80)$ of those who were not hurt in World War II [i.e., $12 \%$ more by the former group than by the latter; $\left.\chi^{2}(2)=7.46, p<.05\right]$. The percentage of students who were hurt by World War II was $77.40 \%(274 / 354)$.

The results concerning the comparison between the 6-Day and Yom Kippur wars also bore out our prediction on the effect of economic losses on security ranking. Unexpectedly, however, we did find that after the Yom Kippur War, security was ranked higher than after the 6-Day War by $11 \%$ more students who had suffered economic injury in World War II than by students who had not $\left[\chi^{2}(2)=6.73, p<.05\right]$. This result may be attributed to the fact that $88 \%$ of those who had suffered physically in World War II had suffered economic injury as well, whereas only $62 \%$ suffered similarly as a result of the Yom Kippur War. Other results showed no significant relationship between economic losses and security ranking.

Another enticing question is whether or not there is a link between our independent variables and the actual electoral preferences of the respondents for the seventh (1969) and eighth (1973) Knesset, and for changes in their party choices between these two elections. No significant chi-square relations were found. This may be attributed to two general factors. First, the Israeli party system represents a complex network of cross-cutting cleavages, of which the security issue is a prominent one (cf. Arian, 1973; Torgovnik, 1975), and second, the attitude-action inconsistency thesis (cf. Kelman, 1974) pertains to the topics under discussion, too.

\section{DISCUSSION}

The data indicated that fear aroused by wars is associated with the tendency to give priority to security based on physical force. First, physical injury in the Yom Kippur War increased the tendency to rank security above other considerations in both the Knesset elections and the rank ordering of national goals after the Yom Kippur War. Second, physical injury both in World War II and in the Yom Kippur War resulted significantly in a tendency to rank order security based on military power uppermost among national goals after the Yom Kippur War. Third, physical injury incurred during World War II resulted in a marked tendency to put security through force higher on the national agenda after the Yom Kippur War than after the 6-Day War of 1967.

Conversely, it has been shown that if no fear was aroused by these two wars, there was no tendency to give priority to security based on force. First, physical injury in World War II and the Yom Kippur War had no significant impact on the ranking of security after the 1967 war, retrospectively. Second, economic injury did not increase the tendency to give priority to security through force.

It should be noted that although the present study is an ex post facto design, one can still specify direction of causality, since World War II and the Yom Kippur War occurred before the research was conducted. First, it would be illogical to assume that Israeli security through force might have caused World War II. Second, since everyone in Israel has to serve in the army, since the Yom Kippur War came upon Israel as a surprise, and since almost the whole nation was fighting for its survival, it is improbable to suggest that those who had a "hawkish" attitude before the Yom Kippur War had greater chances of being injured by this war than those who had a "dovish" attitude. Thus, it is reasonable to assume in the present case that fear aroused by being hurt in World War II and in the Yom Kippur War affected security ranking, rather than to assume the opposite direction of causality.

Can the results be accounted for by other explanations, which do not refer to the concept of fear? For example, people who have been hurt in a war might emphasize military security by reasoning that a well-prepared army might prevent a war or reduce its damages. While this commonsensical hypothesis may account for the increase in security ratings after a war, it encounters some difficulties in explaining all the results. According to this hypothesis, one would predict, first, that people who were physically hurt in World War II or in the 1973 war would retrospectively emphasize security through force after the 6-Day War, which ostensibly vindicated this commonsensical approach by being a major success, and second, that people who were hurt in these wars would stress security through force equally after the 6-Day War and after the 1973 war. The results do not confirm these predictions. Third, according to this hypothesis, one would predict that people who suffered personal economical injury in a war would emphasize military security more than people who were not hurt. The results do not confirm this prediction, either.

Alternatively, injured people may become more "hawkish," since they are more aggressive or because they try to justify their suffering. Here, again, it would be difficult to explain the effect of economic losses (which probably aroused aggression) and the perception of the 6-Day War (which presumably aroused justification) on security rating without referring to fear. 
The final question related to the aggregate political implication of the findings. As we have pointed out above, there is no simple link between the independent variables and electoral choices. However, there are two other respects in which our findings might have some bearings on state behavior. First, although our sample did not include Israeli foreign policy decision makers, it may be quite plausibly assumed that the decision makers as individuals are just as susceptible to the effects of our independent variables as are ordinary citizens. Second, decision makers are affected, also, indirectly through the expectations and demands of the general public, which, as has been pointed out by Kelman (1965), is basically an aggregate of individual responses to the same variables. The sum total is an aggregate national response that is very nearly identical to the individual, specific response as proposed here.

\section{REFERENCES}

ArIAN, A. The choosing people: Voting behavior in Israel. Cleveland, Ohio: Cleveland Press of Case Western Reserve University, 1973.

Brown, J. S. Factors affecting self-punitive behavior. In B. A. Campbell \& R. M. Church (Eds.), Punishment and aversive behavior. New York: Appleton, 1969.

Deutsch, K. W., \& SenghaAs, D. Die Bruchige Vernunft von Staaten. In D. Senghaas (Ed.), Kritische Friedens Forschung. Frankfurt: Shurkamp, 1971.

Gladstone, A. I., \& TAylor, M. A. Threat-related attitudes and reactions to communications about international events. Journal of Conflict Resolution, 1958, 3, 17-28.

Holsti, O. R. The belief system and national images: A case study. Journal of Conflict Resolution, 1962, 6, 244-252.
Kelman, H. C. Social-psychological approaches to the study of international relations: The question of relevance. In $\mathbf{H}$. C. Kelman (Ed.), International behavior, a social-psychological analysis. New York: Holt, Rinehart, \& Winston, 1965.

Kelman, H. C. Attitudes are alive and well and gainfully employed in the sphere of action. American Psychologist, 1974, 29, 310-324.

Mowrer, O. H. On the dual nature of learning-A reinterpretation of "conditioning" and "problem solving." Harvard Educational Review, 1947, 17, 102-148.

Pruitr, G. Definition of the situation as a determinant of international action. In H. C. Kelman (Ed.), International behavior, a social-psychological analysis. New York: Holt, Rinehart, \& Winston, 1965.

Renner, K. E., \& Tinsley, J. B. Self-punitive behavior. In G. H. Bower (Ed.), The psychology of learning and motivation: Advances in research and theory. New York: Academic Press, 1976.

Scotr, W. A. Psychological and social correlates of international images. In H. C. Kelman (Ed.), International behavior, a socialpsychological analysis. New York: Holt, Rinehart, \& Winston, 1965.

Torgovnik, A. The election campaign: Party needs and voter concerns. In A. Arian (Ed.), The elections in Israel-1973. Jerusalem: Jerusalem Academic Press, 1975.

WiNER, B. G. Statistical principles in experimental design (2nd ed.). New York: McGraw-Hill, 1971.

ZinNes, D. A. Hostility in international decision-making. Journal of Conflict Resolution, 1962, 6, 236-243.

(Received for publication July 28, 1980.) 